The effect of irrigation and nitrogen fertilization on the soybean seed yield, with a correlation to the protein and oil concentration

Efekt navodnjavanja i gnojidbe dušikom na prinos sjemena soje $\mathrm{s}$ korelacijom u odnosu na koncentraciju bjelančevina i ulja

Galić Subašić, D., Jurišić, M., Jug, I., Josipović, M., Kiš, D., Rapčan, I.

Poljoprivreda/Agriculture

ISSN: 1848-8080 (Online)

ISSN: 1330-7142 (Print)

https://doi.org/10.18047/poljo.26.2.6

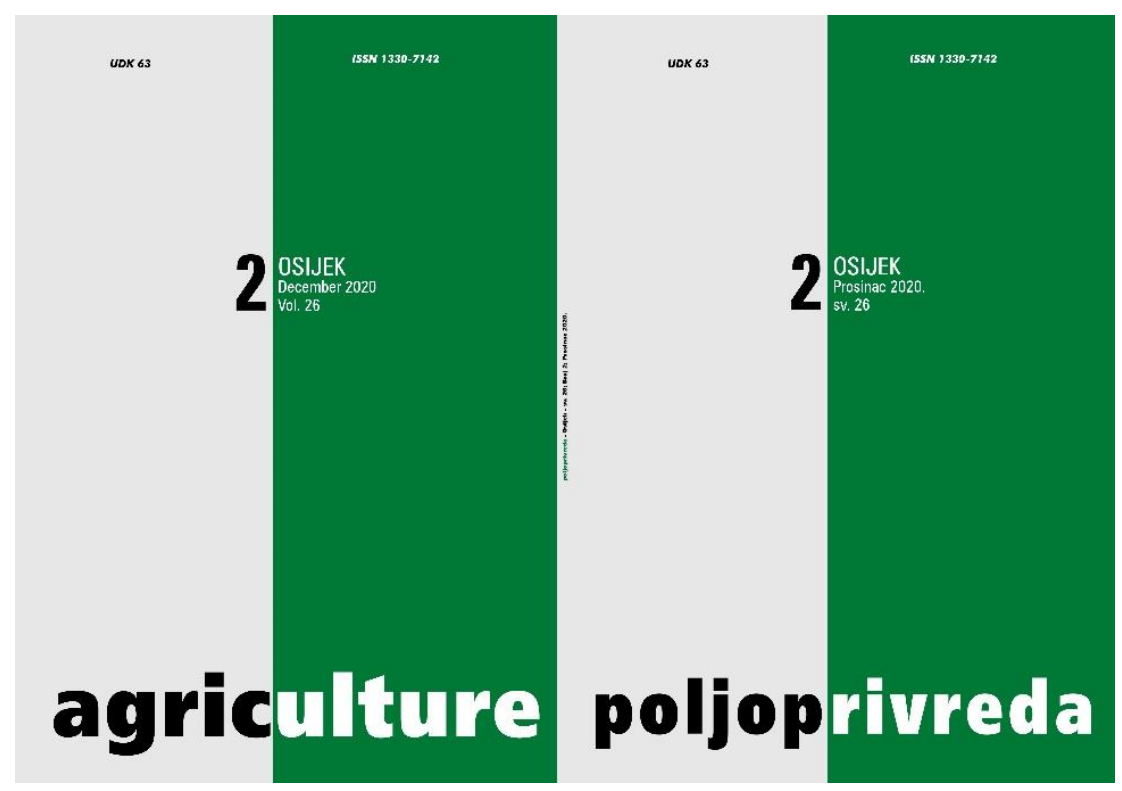

Fakultet agrobiotehničkih znanosti Osijek, Poljoprivredni institut Osijek

Faculty of Agrobiotechnical Sciences Osijek, Agricultural Institute Osijek 


\title{
THE EFFECT OF IRRIGATION AND NITROGEN FERTILIZATION ON THE SOYBEAN SEED YIELD, WITH A CORRELATION TO THE PROTEIN AND OIL CONCENTRATION
}

Galić Subašić, D. ${ }^{(1)}$, Jurišić, M. ${ }^{(1)}$, Jug, I. ${ }^{(1)}$, Josipović, M. ${ }^{(2)}$, Kiš, D. ${ }^{(1)}$, Rapčan, I. ${ }^{(1)}$

Original scientific paper

Izvorni znanstveni članak

\begin{abstract}
SUMMARY
The paper presents the result of a triennial field experiment (2013-15), aiming to determine the influence of irrigation, nitrogen fertilization, and cultivars, as well as their interactions on the yield and chemical properties of the soybean seeds. Four soybean cultivars (Lucija, Vita, Ika and Tena) of different maturity groups were investigate as a sub-subplot factor (C). The main plot factor (A - irrigation) resulted in a statistically very significant $(P \leq 0.01)$ seed yield in all three years, and it was found out by an analysis of variance. The subplot factor ( $B$ - nitrogen fertilization) had an impact on the grain yield depending on the research year, while sub-subplot factor (C-cultivar) significantly affected all examined traits. The factor interactions and their significance varied by the research years. The seed yield achieved in $2013\left(3883 \mathrm{~kg} \mathrm{ha}^{-1}\right)$ indicated a great importance of all factors' interaction. The correlations between a seed yield and a protein and oil concentration were determined during the research.
\end{abstract}

Keywords: soybean, irrigation, nitrogen fertilization, cultivar, seed yield, seed protein concentration, seed oil concentration, correlations

\section{INTRODUCTION}

Soybean (Glycine max (L.) Merr.) is an important legume that provides a primary source of high-quality plant proteins and oils. Commercial soybean cultivars contain approximately $40 \%$ of proteins, $20-22 \%$ of oils, $34 \%$ carbohydrates, $5 \%$ of minerals (potassium, phosphorus, sulfur, calcium, iron, magnesium, sodium) and vitamins $\mathrm{A}, \mathrm{B}$-complex, D, E and $\mathrm{K}$ in the grain (Vrataric and Sudarić, 2008). Due to the quality proteins and a high concentration of oil, soybean is a substitute for meat more than other crops (Sudarić, 2011). Soybean oil is rich in omega-3 $(7-8 \%)$ and omega- 6 fatty acids $(55 \%)$, and thus it serves as a raw material for a large number of industrial products (List, 2016). An increase in the soybean seed use in the domestic animals feeding, the processing industry, and human diet resulted in a greater need for a larger quantity and quality of proteins and oils (Umburanas, 2018).

Soybean is grown on the areas exceeding the acreage of 120 million hectares (FAO, 2017). The largest producer of soybean in Europe is Russia, and globally the United States, Brazil, Argentina, and China. The Republic of Croatia records a continuous increase in soybean production (Jukić et al., 2010). Pursuant to the data provided by the Central Bureau of Statistics in 2018, soybean production in 2017 was organized on 85,000 ha, with an average yield amounting to $2.4 \mathrm{t}$ $\mathrm{ha}^{-1}$. Increasingly frequent climate change causes crop cultivation's dependency on the irrigation application (Tomić, 2012). Irrigation was recommended as a mandatory agrotechnical measure, aiming to obtain higher and more stable yields, since there was a constant lack of precipitation during soybean growing season in the study area on a multi-year average (1961-90). Water scarcity has significant consequences on grain yield and its quality (Adeboye et al., 2015). Due to a higher

(1) Daria Galić Subašić, Ph. D., Senior Expert Associateldgsubasic@ fazos.hr), Prof. Dr. Mladen Jurišić, Prof. Dr. Irena Jug, Prof. Dr. Darko Kiš, Prof. Dr. Irena Rapčan - Josip Juraj Strossmayer University of Osijek, Faculty of Agrobiotechnical Sciences Osijek, Vladimira Preloga 1, 31000 Osijek, Croatia, (2) Marko Josipović, Ph. D., Scientific Adviser (tenured), Agricultural Institute Osijek, Južno predgrađe 17, 31000 Osijek, Croatia 
food demand, there was a need for sustainable solutions to combat productivity loss caused by a water stress (Prudent et al., 2015). Thus, irrigation had a statistically significant effect on water scarcity mitigation (Zhang et al., 2015). The amount of available nitrogen should be sufficient to ensure high yields of an appropriate quality (Đukić et al., 2014). Increased nitrogen fertilization is justified the pertaining to the soils having a lower fertility at low soilborne $\mathrm{pH}$ reactions, where the conditions for the development of nodule bacteria are not met. Climatic, edaphic, and orographic factors primarily affect the realization of soybean yield genetic potential. Registered cultivars of the Agricultural Institute Osijek significantly contribute to the horizontal and vertical soybean production increase in the country. They are known for high yield genetic potential and a wide adaptability to the unfavorable abiotic factors (Sudaric et al., 2012). Quantity and quality of soybean seeds can be significantly improved by regulating the water content in the soil, proper nitrogen fertilization, and cultivar selection.

\section{MATERIAL AND METHODS}

In order to determine the impact of irrigation, nitrogen fertilization, and cultivars on the yield and chemical properties of soybean, a three-year (2013-15) field experiment was conducted on the areas of the Agricultural Institute in 0sijek $\left(45^{\circ} 32^{\prime} \mathrm{N}\right.$ and $18^{\circ} 44^{\prime} \mathrm{E}$, $88 \mathrm{~m}$ above sea level). The experiment was performed according to a plan featuring the divided plots (split-split plot method in three replications). The influence of three factors was investigated: factor $A$ - irrigation (main plot factor), factor $B$ - nitrogen fertilization (subplot factor) and factor C - soybean cultivar (sub-subplot factor). The size of the main factor's experimental plots was 360 $\mathrm{m}^{2}$, the subfactor amounted to $120 \mathrm{~m}^{2}$, and the subsubfactor amounted to $30 \mathrm{~m}^{2}$. Four cultivars (C1-Lucija, C2 - Vita, C3 - lka and C4 - Tena) of different maturity groups produced by the Agricultural Institute Osijek have been used. Each of them was sown in five rows, three of which were the harvest rows, $20 \mathrm{~m}$ long, with a $50-\mathrm{cm}$ row spacing. The irrigation was conducted in three treatments: A1 - control treatment (rainfall), A2 rational irrigation, whereby the soil water content was maintained from $60 \%$ to $100 \%$ RCW (soil water retention capacity), and the $\mathrm{A} 3$ treatment - rich irrigation, from $80 \%$ to $100 \%$ RCW). It was performed from sowing to the seed filling by the ration calculated upon the base of soil water properties. The measurement of soil water content is performed by a Watermark device. The moment of irrigation commencement was determined by an electrometric method according to the current soil moisture. The sensors were place at depths of 20 and $30 \mathrm{~cm}$, and two depths average were taken for the moment of irrigation commencement. The sensors were installed in mid-May in all three years. Mineral nitrogen fertilization was performed in three variants: variant B1 - control variant without nitrogen fertilization, variant $\mathrm{B} 2$ - fertilization with $100 \mathrm{~kg} \mathrm{~N}^{-1}$, and variant B3 -fertilization with $200 \mathrm{~kg} \mathrm{~N} \mathrm{ha}^{-1}$. The right amount of urea nitrogen $(46 \% \mathrm{~N})$ was applied twice. A half of the total amount of nitrogen was manually applied on the denoted plots and the experiment variants in the basic autumn fertilization. The other half of the total amount of nitrogen was added in the spring, with a pre-sowing soil preparation. The sowing was performed by a pneumatic 12-row sowing machine in the optimal agrotechnical period for this area, whereas harvesting was performed by a combine harvester for the Wintersteiger experiment types. The seeds quantity obtained was weighed for each plot and converted into $\mathrm{kg} \mathrm{ha}^{-1}$. The precipitation amount and distribution in the soybean growing season (from April to September) in a triennial research varied significantly and differently affected the dynamics of soil water content. Accordingly, the number and schedule of irrigation ration differed, too. In the first year of research, $105 \mathrm{~mm}$ of water was added to the variant $A 2$ in three equal irrigation rations. The total amount of added water in the variant $A 3$ was 210 $\mathrm{mm}$. A total of $140 \mathrm{~mm}$ was applied to the variant $\mathrm{A} 2$ and $175 \mathrm{~mm}$ to the $A 3$ in 2014. In the third year of the research, the same amount of water was added in the same number of rations as in the first year. Soybean was irrigated by the rain method and a self-propelled sector sprayer (Typhon), with an average speed of 0.18 $\mathrm{m} \mathrm{min}^{-1}$, ranging from 22 to $25 \mathrm{~m}$. The working pressure of the sprayer water outlet was up to 2.5 bars. The source of irrigation water was groundwater (a nearby well). Laboratory analyses of the seed quality were conducted in the laboratory of the Agricultural Institute 0sijek. The protein and oil concentrations were determined by the near-infrared transmission (Infratec S009011 Analyzer). A statistical analysis was perform using the computer program Statistica 12 (StatSoft Inc., 2012) and Microsoft Excel. The amount, distribution, and intensity of precipitation, as well as that of the air temperature, varied over the research years. All experiment years were warmer than the average (by $0.78^{\circ} \mathrm{C}$, $1.49^{\circ} \mathrm{C}$, and $1.34^{\circ} \mathrm{C}$, respectively). During the growing season, $30 \mathrm{~mm}$ and $132.7 \mathrm{~mm}$ more precipitation fell in the years 2013 and 2014, compared to the average, whereas in 2015 only $315 \mathrm{~mm}$ fell, being 74.7 less than the average. The drought period in the first year lasted from July to mid-August, being in line with the stages of flowering and seed filling. In 2014, there was a shorter period of a lower-intensity drought. The dry period, common to this agroecological area, has not been recorded, and a significant amount of precipitation fell in the estival months. The climate indicators monitored in 2015 manifested a distinct deviation from a multiannual average for this area. The periods of higher-intensity drought were recorded from April to June and in July, including a part of August, which characterized this year as a dry one, compared to a multiannual average. 


\section{RESULTS AND DISCUSSION}

A soybean seed yield average of $3,770 \mathrm{~kg} \mathrm{ha}^{-1}$ was determined with the yield variations of $3883 \mathrm{~kg}$ ha- ${ }^{1}$ (2013), $3803 \mathrm{~kg} \mathrm{ha}^{-1}$ (2014), and $3625 \mathrm{~kg} \mathrm{ha}^{-1}$ (2015). In all research years, the irrigation applied was justified, since the variants of rational and abundant irrigation had a statistically very significant $(P<0.01)$ higher yield than the control one (Table 1-3). Climatic conditions can cause higher variations in yield per years, whereby the temperature régime has a slightly lower impact than precipitation and air humidity (Josipović et al., 2011). There were two warm estival periods in the first and second research year, whereas this period was extremely warm in 2015. July of the first and of the third research year was characterized by significantly higher air temperatures when compared to the average. The drought period in 2013 lasted from June to August, and thus the variant rich in irrigation proved to be justified, since the obtained yield in the A3 variant was by $25 \%$ higher when compared to the control one (Table 1).

Table 1. The impact of irrigation (A), nitrogen fertilization (B), and cultivar (C) on the soybean seed yield $\left(\mathrm{kg} \mathrm{ha}^{-1}\right)$, with the associated $L S D(P=0.05$ and $P=0.01)$ and $F$ values in 2013

Tablica 1. Utjecaj čimbenika navodnjavanja (A), gnojidbe dušikom (B) i sorte (C) na prinos zrna $\left(\mathrm{kg} \mathrm{ha}^{-1}\right)$ soje s pripadajućim $L S D(P=0,05$ i $P=0,01)$ i F vrijednostima u 2013. godini

\begin{tabular}{|c|c|c|c|c|c|}
\hline \multicolumn{3}{|c|}{$\begin{array}{l}\text { Irrigation impact on the soybean seed yield } \\
\qquad\left(\mathbf{k g ~ h a}^{-1}\right) \\
\text { Utjecaj navodnjavanja na prinos zrna soje } \\
\left(\mathrm{kg} \mathrm{ha}^{-1}\right)\end{array}$} & \multicolumn{3}{|c|}{$\begin{array}{l}\text { Nitrogen fertilization impact on the soybean seed yield } \\
\qquad \begin{array}{l}\left(\mathbf{k g ~ h a}^{-1}\right) \\
\text { Utjecaj gnojidbe dušikom na prinos zrna soje } \\
\left(\mathrm{kg} \mathrm{ha}^{-1}\right)\end{array}\end{array}$} \\
\hline $\begin{array}{l}A_{1} \\
A_{2} \\
A_{3}\end{array}$ & & & $\begin{array}{l}\mathrm{B}_{1} \\
\mathrm{~B}_{2} \\
\mathrm{~B}_{3}\end{array}$ & & \\
\hline $\begin{array}{l}\text { LSD } 5 \% \\
79.12\end{array}$ & $\begin{array}{l}\text { LSD } 1 \% \\
104.15\end{array}$ & $\begin{array}{c}\mathrm{F} \text { test } \\
238.68^{* *}\end{array}$ & $\begin{array}{l}\text { LSD 5\% } \\
98.01\end{array}$ & $\begin{array}{l}\text { LSD } 1 \% \\
129.00\end{array}$ & $\begin{array}{l}\text { F test } \\
9.92^{* *}\end{array}$ \\
\hline \multicolumn{6}{|c|}{$\begin{array}{l}\text { Cultivar impact on the soybean seed yield }\left(\mathbf{k g ~ h a} \mathbf{a}^{-1}\right) \\
\text { Utjecaj sorte na prinos zrna soje }\left(\mathrm{kg} \mathrm{ha}^{-1}\right)\end{array}$} \\
\hline $\begin{array}{l}\mathrm{C}_{1} \\
\mathrm{C}_{2} \\
\mathrm{C}_{3} \\
\mathrm{C}_{4}\end{array}$ & \multicolumn{2}{|c|}{$\begin{array}{l}3629 \\
3816 \\
4063 \\
4022\end{array}$} & \multicolumn{3}{|c|}{$\begin{array}{l}\text { Significant interaction A x B } \\
\text { Značajna interakcija } A \times B\end{array}$} \\
\hline \multirow[t]{2}{*}{$\begin{array}{l}\text { LSD } 5 \% \\
64.93\end{array}$} & $\begin{array}{l}\text { LSD } 1 \% \\
87.69\end{array}$ & $\begin{array}{c}\text { F test } \\
80,15^{* *}\end{array}$ & $\begin{array}{l}\text { LSD } 5 \% \\
188.72\end{array}$ & $\begin{array}{l}\text { LSD } 1 \% \\
264.59\end{array}$ & $\begin{array}{c}\text { F test } \\
13.45^{* *}\end{array}$ \\
\hline & \multicolumn{2}{|c|}{$\begin{array}{c}\text { Significant interaction A x C } \\
\text { Značajna interakcija } A \times C\end{array}$} & \multicolumn{3}{|c|}{$\begin{array}{c}\text { Significant interaction B x C } \\
\text { Značajna interakcija } B \times C\end{array}$} \\
\hline $\begin{array}{l}\text { LSD } 5 \% \\
123.98\end{array}$ & $\begin{array}{l}\text { LSD } 1 \% \\
178.13\end{array}$ & $\begin{array}{l}\text { F test } \\
9.27^{* *}\end{array}$ & $\begin{array}{r}\text { LSD } 5 \% \\
123.98\end{array}$ & $\begin{array}{l}\text { LSD } 1 \% \\
178.13\end{array}$ & $\begin{array}{l}\text { F test } \\
11.83^{* *}\end{array}$ \\
\hline \multicolumn{6}{|c|}{$\begin{array}{l}\text { Significant interaction A x B x C } \\
\text { Značajna interakcija } A \times B \times C\end{array}$} \\
\hline & $\begin{array}{l}\text { LSD } 5 \% \\
302.07\end{array}$ & $\begin{array}{l}\text { LSD 1\% } \\
554.50\end{array}$ & $\begin{array}{c}\text { F test } \\
15.24^{* *}\end{array}$ & & \\
\hline
\end{tabular}

$\mathrm{A} 1=$ control, $\mathrm{A} 2=60-100 \% \mathrm{RCW}, \mathrm{A} 3=80-100 \% \mathrm{RCW} ; \mathrm{B} 1=0 \mathrm{~kg} \mathrm{~N} \mathrm{ha}^{-1}, \mathrm{~B} 2=100 \mathrm{~kg} \mathrm{~N} \mathrm{ha}^{-1}, \mathrm{~B} 3=200 \mathrm{~kg} \mathrm{~N} \mathrm{ha}^{-1} ; \mathrm{C} 1=$ Lucija, C2 $=$ Vita, C3 =lka, C4 $=$ Tena; $\mathrm{AB}=$ irrigation $\mathrm{x}$ fertilization, $\mathrm{BC}=$ fertilization $\mathrm{x}$ cultivar, $\mathrm{AC}=$ irrigation $\mathrm{x}$ cultivar, $\mathrm{ABC}=$ irrigation $\mathrm{x}$ fertilization $\mathrm{x}$ cultivar; ${ }^{*}=\mathrm{P} \leq 0.05 ;{ }^{* *}=\mathrm{P} \leq 0.01$

Similar results were obtained by Sincik et al. (2008) in their research. The greatest effect of irrigation on yield was recorded in 2015 (Table 3), in a longer dry period, when the soybeans were sensitive to a water shortage (flowering and seed filling). In the rich irrigation treat- ment $(\mathrm{A} 3)$, the yield was higher by $9 \%$, related to a rational irrigation (A2) treatment of, i.e., it was higher by $37 \%$ when compared to the control treatment (A1). This is in accordance with the research results by Šimunić et al. (2011) and Kresović et al. (2016). 
Table 2. The influence of irrigation (A), nitrogen fertilization (B), and cultivar (C) on the soybean seed yield ( $\mathrm{kg}$ ha $\left.^{-1}\right)$, with the associated $\mathbf{S D}(\mathbf{P}=\mathbf{0 . 0 5}$ and $\mathbf{P}=\mathbf{0 . 0 1})$ and $\mathrm{F}$ values in 2014

Tablica 2. Utjecaj čimbenika navodnjavanja (A), gnojidbe dušikom(B) i sorte (C) na prinos zrna $\left(\mathrm{kg} \mathrm{ha}^{-1}\right)$ soje s pripadajućim $L S D(P=0,05$ i $P=0,01)$ i F vrijednostima u 2014. godini

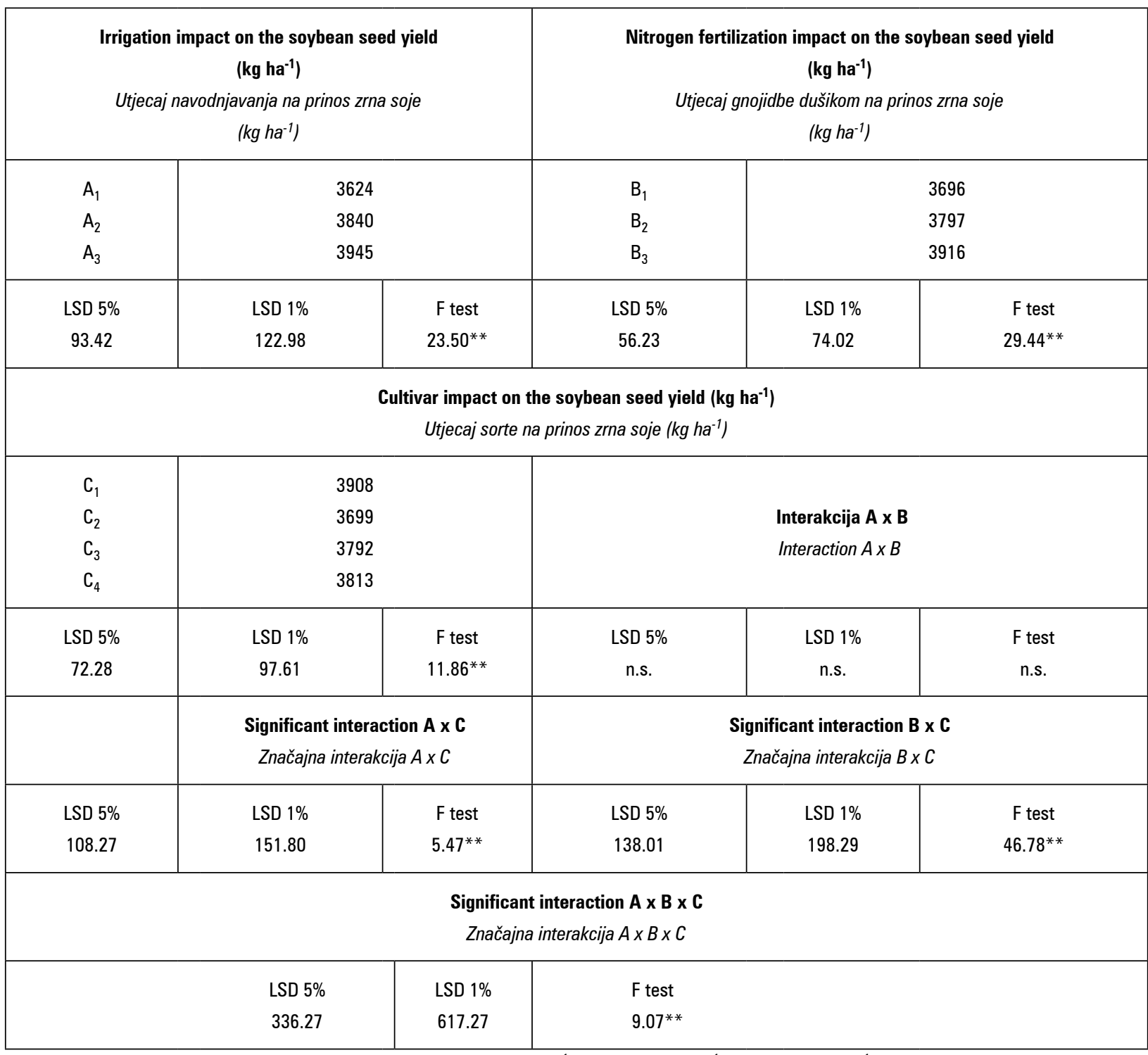

$\mathrm{A} 1=$ control, $\mathrm{A} 2=60-100 \% \mathrm{RCW}, \mathrm{A} 3=80-100 \% \mathrm{RCW} ; \mathrm{B} 1=0 \mathrm{~kg} \mathrm{~N} \mathrm{ha}^{-1}, \mathrm{~B} 2=100 \mathrm{~kg} \mathrm{~N} \mathrm{ha}^{-1}, \mathrm{~B} 3=200 \mathrm{~kg} \mathrm{~N} \mathrm{ha}^{-1} ; \mathrm{C} 1=$ Lucija, C2 = Vita, C3 = lka, C4

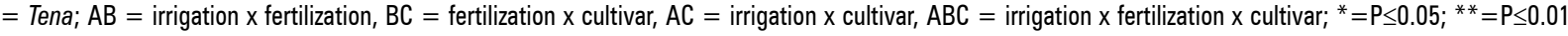

Mineral nitrogen fertilization had a very significant effect on the soybean seed yield in the B2 and B3 treatments during all three research years. Significantly higher soybean yields were achieved in the treatment with $200 \mathrm{~kg} \mathrm{~N} \mathrm{ha}^{-1}$, if compared to a treatment with $100 \mathrm{~kg} \mathrm{~N} \mathrm{ha}^{-1}$ and the 2013 and 2014 research control (Tables 1 and 2). However, in 2015, the control yield was significantly lower if compared to other fertilization treatments, with no justified differences between them (Table 3). The results obtained are in line with some other results (Esmaili et al., 2012; La Menza et al., 2017). The highest grain yields were achieved by the cultivars lka (4063 $\mathrm{kg} \mathrm{ha}^{-1}$ ) and Tena (4022 kg ha-1) in 2013 (Table 1). All soybean cultivars obtained the lowest yield in the conditions without irrigation, whereas each higher level of irrigation resulted in a significantly higher soybean yield in the dry year 2015, (Table 3). Similarly, Garcia et al. (2010) identified the genotypic differences in the water use efficiency. Chafi et al. (2012) stated that the irrigation and nitrogen fertilization treatments significantly affected the seed yield of the investigated cultivar pointing out the importance of cultivar selection to achieve optimal yields with reduced water use. 
Table 3. Influence of irrigation (A), nitrogen fertilization (B) and genotype (C) on soybean seed yield (kg $\mathbf{~ h a}^{-1}$ ) with associated LSD ( $P=\mathbf{0 . 0 5}$ and $P=\mathbf{0 . 0 1})$ and $F$ values in 2015

Tablica 3. Utjecaj čimbenika navodnjavanja (A), gnojidbe dušikom (B) i sorte (C) na prinos zrna $\left(\mathrm{kg} \mathrm{ha}^{-1}\right)$ soje s pripadajućim $L S D(P=0,05$ i $P=0,01)$ i F vrijednostima u 2015. godini

\begin{tabular}{|c|c|c|c|c|c|}
\hline \multicolumn{3}{|c|}{$\begin{array}{l}\text { Irrigation impact on the soybean seed yield } \\
\text { (kg ha-1) } \\
\text { Utjecaj navodnjavanja na prinos zrna soje } \\
\left(\mathrm{kg} \mathrm{ha}^{-1}\right)\end{array}$} & \multicolumn{3}{|c|}{$\begin{array}{c}\text { Nitrogen fertilization impact on the soybean seed yield } \\
\qquad\left(\mathbf{k g ~ h a} \mathbf{~}^{-1}\right) \\
\text { Utjecaj gnojidbe dušikom na prinos zrna soje } \\
\left(\mathrm{kg} \mathrm{ha}^{-1}\right)\end{array}$} \\
\hline$A_{1}$ & \multicolumn{2}{|c|}{2999} & $B_{1}$ & \multicolumn{2}{|c|}{3395} \\
\hline $\mathrm{A}_{2}$ & \multicolumn{2}{|c|}{3772} & $\mathrm{~B}_{2}$ & \multicolumn{2}{|c|}{3705} \\
\hline $\mathrm{A}_{3}$ & \multicolumn{2}{|c|}{4104} & $\mathrm{~B}_{3}$ & \multicolumn{2}{|c|}{3775} \\
\hline LSD 5\% & LSD 1\% & $\mathrm{F}$ test & LSD $5 \%$ & LSD 1\% & $\mathrm{F}$ test \\
\hline 159.31 & 209.70 & $97.19 * *$ & 95.26 & 125.39 & $34.64^{* *}$ \\
\hline \multicolumn{6}{|c|}{$\begin{array}{l}\text { Cultivar impact on the soybean seed yield (kg ha-1) } \\
\text { Utjecaj sorte na prinos zrna soje }\left(\mathrm{kg} \mathrm{ha}^{-1}\right)\end{array}$} \\
\hline $\mathrm{C}_{1}$ & \multirow{4}{*}{\multicolumn{2}{|c|}{$\begin{array}{l}3646 \\
3341 \\
3761 \\
3752\end{array}$}} & \multirow{4}{*}{\multicolumn{3}{|c|}{$\begin{array}{c}\text { Significant interaction A x B } \\
\text { Značajna interakcija } A \times B\end{array}$}} \\
\hline $\mathrm{C}_{2}$ & & & & & \\
\hline $\mathrm{C}_{3}$ & & & & & \\
\hline $\mathrm{C}_{4}$ & & & & & \\
\hline LSD 5\% & LSD 1\% & F test & LSD 5\% & LSD 1\% & F test \\
\hline \multirow[t]{2}{*}{137.75} & 186.01 & $17.14^{* *}$ & 183.43 & 257.17 & $18.19 * *$ \\
\hline & \multicolumn{2}{|c|}{$\begin{array}{l}\text { Interaction A x C } \\
\text { Interakcija } A \times C\end{array}$} & & \multicolumn{2}{|c|}{$\begin{array}{l}\text { Interaction B x C } \\
\text { Interakcija } B \times C\end{array}$} \\
\hline $\begin{array}{l}\text { LSD } 5 \% \\
\text { n.s. }\end{array}$ & $\begin{array}{l}\text { LSD } 1 \% \\
\text { n.s. }\end{array}$ & $\begin{array}{l}\text { F test } \\
\text { n.s. }\end{array}$ & $\begin{array}{l}\text { LSD } 5 \% \\
\text { n.s. }\end{array}$ & $\begin{array}{l}\text { LSD } 1 \% \\
\text { n.s. }\end{array}$ & $\begin{array}{l}\text { F test } \\
\text { n.s. }\end{array}$ \\
\hline \multicolumn{6}{|c|}{$\begin{array}{c}\text { Significant interaction A x B x C } \\
\text { Značajna interakcija } A \times B \times C\end{array}$} \\
\hline & LSD 5\% & LSD $1 \%$ & $\mathrm{Ft}$ & & \\
\hline & 640.81 & 1176.29 & 4.1 & & \\
\hline
\end{tabular}

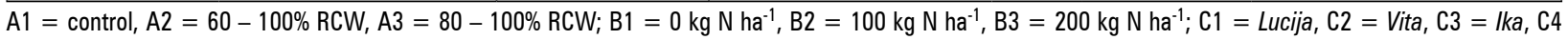
$=$ Tena; $\mathrm{AB}=$ irrigation $x$ fertilization, $\mathrm{BC}=$ fertilization $\mathrm{x}$ cultivar, $\mathrm{AC}=$ irrigation $\mathrm{x}$ cultivar, $\mathrm{ABC}=$ irrigation $\mathrm{x}$ fertilization $\mathrm{x}$ cultivar; ${ }^{*}=\mathrm{P} \leq 0.05 ;{ }^{* *}=\mathrm{P} \leq 0.01$

Numerous researches have concluded that the soybean seed oil and protein concentrations are significantly influenced by genetic specificity, and that the grain yield and its quality are the primary targets of soybean breeding (Sudarić et al., 2009). A statistically very significant difference $(P \leq 0.01)$ in the soybean seed yield in certain experiment variants was record in the interaction of all three factors - the irrigation, nitrogen fertilization, and the soybean cultivar $(\mathrm{AxBxC})$ in 2013. As per all factors' interaction, the yield range amounted to $2,634 \mathrm{~kg} \mathrm{ha}^{-1}$ in the experiment with the A1B1C2 variants, with a yield increase (by $2130 \mathrm{~kg}$ $\mathrm{ha}^{-1} \mathrm{l}$ ) in the variant $\mathrm{A} 3 \mathrm{~B} 3 \mathrm{C} 3$. An interaction of all three factors on the 2014 yield also demonstrated a statistically very significant difference. The highest average yield was achieved in the A1B2C3 combination of the treatments set with the Ika cultivar (4513 kg ha-1) and the lowest one with the Vita cultivar, amounting to $3,198 \mathrm{~kg} \mathrm{ha}^{-1}$ and in the A1B2C4 combination. A statistically significant $(P \leq 0.05)$ interaction of irrigation and nitrogen fertilization $(\mathrm{A} \times \mathrm{B})$ was found in the seed yield in 2015 . The highest yield $\left(4,285 \mathrm{~kg} \mathrm{ha}^{-1}\right)$ was obtained in the $\mathrm{A} 3 \mathrm{~B} 3$ combination, whereas the lowest, $2,468 \mathrm{~kg} \mathrm{ha}^{-1}$, was achieved in the control treatment. A triennial research average demonstrates two experiment variants, characterized by a high and a very high seed yield, compared to all other variants. In 2013, the A3B3C3 variant resulted in a yield amounting to $4,764 \mathrm{~kg} \mathrm{ha}^{-1}$, whereas the A3B3C4 variant obtain a yield of $4,557 \mathrm{~kg} \mathrm{ha}^{-1}$ in 2015 . The A1B1C2 variant was low and had a significantly lower yield $(1981 \mathrm{~kg}$ $\mathrm{ha}^{-1}$ ) in 2015. In all three research years, the protein and oil concentrations in the soybean seeds were recorded (data not shown) and correlations with seed yield were established, with the significant ones being depicted in Graph 1. The strongest negative correlation was determined in the experiment's last year between the soybean seed protein and oil concentrations $(r=$ $-0.767^{* *}$, Graph 1e) and in the first year ( $r=-0.560^{*}$, Graph $1 \mathrm{~b}$ ), being in harmony with some previous researches (Popović et al., 2012). An observed negative correlation between the yield and oil concentration (Graphs 1a, 1d) in 2013 in 2015 was confirmed by Chung et al. (2003). 

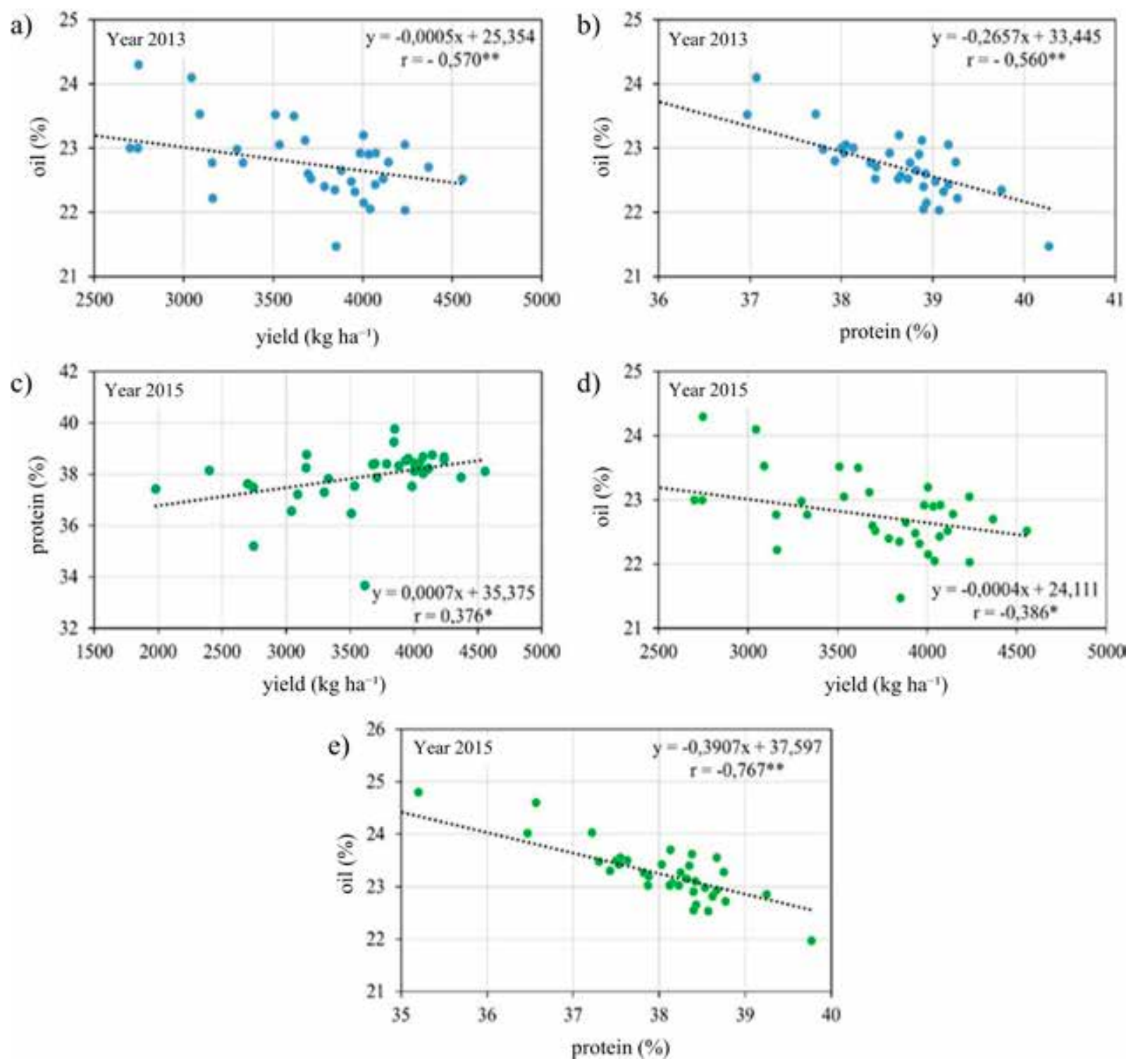

Graph 1. The correlations between an oil concentration and the seed yield in 2013 (a), between the oil and protein concentrations in 2013 (b), between a protein concentration and the seed yield in 2015(c), between an oil concentration and the seed yield in 2015 (d), and between the oil and protein concentrations in 2015 (e)

Grafikon 1. Korelacije između koncentracije ulja i prinosa zrna u 2013. godini (a), između koncentracija ulja i bjelančevina u 2013. godini (b), između koncentracije bjelančevina i prinosa zrna u 2015. godini (c), između koncentracije ulja i prinosa zrna u 2015. godini (d) te između koncentracija ulja i bjelančevina u 2015. godini (e)

Popović et al. (2012) stated that a correlation of the opposite direction led to the conclusion that the oil content was a cultivar property. A weak correlation of the positive direction $\left(r=0.376^{*}\right)$ was determined in 2015 between the yield and a protein concentration (Graph 1c). The similar results were report by Esmaili et al. (2012) and Varnica et al. (2018) in their research.

\section{CONCLUSION}

The levels of factors' significance and justification pertaining to the examined properties of soybeans were determined by the research in a triennial experiment.
Irrigation affected the seed yield in all three investigated years, since the variants of rational and rich irrigation have demonstrated a statistically very significant higher yield when compared to the control treatment. The highest seed yield $\left(4,228 \mathrm{~kg} \mathrm{ha}^{-1}\right)$ was achieve in 2013 , in the rich irrigation variant. The significantly higher soybean yields were obtained in the treatment with 200 $\mathrm{kg} \mathrm{N} \mathrm{ha}^{-1}$, if compared to the treatment with $100 \mathrm{~kg} \mathrm{~N}$ $\mathrm{ha}^{-1}$ and to the control one, in the research conducted in 2013 and 2014. However, in 2015, the yield in the control treatment was significantly lower when compared to other fertilization treatments. The highest grain yields were achieved by the cultivars $l k a$ and Tena. Numerous 
correlations between the investigated properties were determined by the experiment conducted. The Strong negative-direction correlations were found between the oil and protein seed concentrations in the first and in the third year of experiment. The results obtained in the triennial research can be useful for the producers in Eastern Croatia when selecting the cultivars and applying the agrotechnical measures (irrigation and fertilization) to achieve the high yields and a good soybean seed quality.

\section{REFERENCES}

1. Adeboye, 0. B., Schultz, B., Adekalu, K. 0., \& Prasad, K. (2015). Crop water productivity and economic evaluation of drip-irrigated soybeans (Glycine max L. Merr.). Agriculture \& Food Security, 4(1), 10. https://doi.org/10.1186/s40066-015-0030-8

2. Barker, D. W., \& Sawyer, J. E. (2005). Nitrogen application to soybean at early reproductive development. Agronomy Journal, 97(2), 615-619. https://doi.org/10.2134/agronj2005.0615

3. Candoğan, B. N., \& Yazgan, S. (2016). Yield and quality response of soybean to full and deficit irrigation at different growth stages under sub-humid climatic conditions. Journal of Agricultural Sciences, 22, 129-144.

4. Chafi, A. A., Amiri, E., \& Nodehi, D. A. (2012). Effects of irrigation and nitrogen fertilizer on soybean (Glycine max) agronomic traits. International Journal of Agriculture and Crop Sciences (IJACS), 4(16), 1188-1192.

5. Chung, J., Babka, H. L., Graef, G. L., Staswick, P. E., Lee, D. J., Cregan, P. B., Shoemaker, R. C., \& Specht, J. E. (2003). The seed protein, oil, and yield QTL on soybean linkage group I. Crop Science, 43(3), 1053-1067. https://doi.org/10.2135/cropsci2003.1053

6. Državni zavod za statistiku Republike Hrvatske, 2017. http://www.dzs.hr

7. Đukić, V., Balešević-Tubić, S., Miladinov, Z., Dozet, G., Cvijanović, G., Đorđević, V., \& Cvijanović, M. (2014). Soybean production and a possibility to economize the use of mineral fertilizers. Ratarstvo i povrtarstvo, 51(3), 161-165. https://doi.org/10.5937/ratpov51-6803

8. Esmaili, K. H., Nakhzari, M. A., \& Dadashi, M. R. (2012). Effect of irrigation management and top dress nitrogen application on seed yield and reproductive characteristics of soybean. Journal of Research in Crop Sciences 4 (14), 67-80.

9. Food and Agriculture Organization of the United Nations (FAO), 2017. http://www.fao.org/

10. Garcia, A. G., Persson, T., Guerra, L. C., \& Hoogenboom, G. (2010). Response of soybean genotypes to different irrigation regimes in a humid region of the southeastern USA. Agricultural Water Management, 97(7), 981-987. https://doi.org/10.1016/j.agwat.2010.01.030

11. Josipović, M., Sudarić, A., Kovačević, V., Marković, M., Plavšić, H., \& Liović, I. (2011). Irrigation and nitrogen fertilization influences on properties of soybean (Glycine max (L.) Merr.) varieties. Poljoprivreda, 17(1), 9-15.
12. Jukić, G., Čupić, T., Marić, S., Jukić, R., \& Teodorović, R. (2010). Utjecaj agroekoloških uvjeta na prinos zrna soje. Sjemenarstvo, 27(3/4), 103-112.

13. Kirnak, H., Dogan, E., \& Turkoglu, H. (2010). Effect of drip irrigation intensity on soybean seed yield and quality in the semi-arid Harran plain, Turkey. Spanish Journal of Agricultural Research, 8(4), 1208-1217.

14. Kresović, B. J., Tapanarova, A. Đ., Pejić, B. S., \& Dragović, R. M. (2016). Uticaj režima navodnjavanja na prinos i komponente prinosa soje. Arab Universities Journal of Agricultural Sciences, 61(4), 305-321. https://doi.org/10.2298/JAS1604305K

15. La Menza, N. C., Monzon, J. P., Specht, J. E., \& Grassini, P. (2017). Is soybean yield limited by nitrogen supply? Field Crops Research, 213, 204-212. https://doi.org/10.1016/j.fcr.2017.08.009

16. List, G. R. (2016). Oilseed Composition and Modification for Health and Nutrition. In Functional Dietary Lipids (pp. 23-46). Woodhead Publishing. https://doi.org/10.1016/B978-1-78242-247-1.00002-8

17. Maleki, A., Naderi, A., Naseri, R., Fathi, A., Bahamin, S., \& Maleki, R. (2013). Physiological performance of soybean cultivars under drought stress. Bulletin of Environment, Pharmacology and Life Sciences, 2(6), 38-44.

18. Popović, V., Vidić, M., Tatić, M., Jakšić, S., \& Kostić, M. (2012). Uticaj sorte i godine na prinos i komponente kvaliteta soje. Field \& Vegetable Crops Research/ Ratarstvo i povrtarstvo, 49(1). https://doi.org/10.5937/ratpov49-1140

19. Prudent, M., Salon, C., Souleimanov, A., Emery, R. J. N., \& Smith, D. L. (2015). Soybean is less impacted by water stress using Bradyrhizobium japonicum and thuricin-17 from Bacillus thuringiensis. Agronomy for Sustainable Development, 35(2), 749-757. https://doi.org/10.1007/s13593-014-0256-z

20. Schmitt, M. A., Lamb, J. A., Randall, G. W., Orf, J. H., \& Rehm, G. W. (2001). In-season fertilizer nitrogen applications for soybean in Minnesota. Agronomy Journal, 93(5), 983-988. https://doi.org/10.2134/agronj2001.935983x

21. *StatSoft Inc. STATISTICA (data analysis software system), version 12.

22. Šimunić, I., Cvetković, D., Pospišil, M., \& Husnjak, S. (2011). Utjecaj razmaka cijevne drenaže na drenažni istek i prinos uljane repice i soje. Agronomski glasnik: Glasilo Hrvatskog agronomskog društva, 73(4-5), 189-200.

23. Sincik, M., Candogan, B. N., Demirtas, C., Büyükcangaz, H., Yazgan, S., \& Göksoy, A. T. (2008). Deficit Irrigation of Soya Bean [Glycine max (L.) Merr.] in a Sub-humid Climate. Journal of Agronomy and Crop Science, 194(3), 200-205.

https://doi.org/10.1111/j.1439-037X.2008.00307.x

24. Sohrabi, Y., Habibi, A., Mohammadi, K., Sohrabi, M., Heidari, G., Khalesro, S., \& Khalvandi, M. (2012). Effect of nitrogen ( $N$ ) fertilizer and foliar-applied iron (Fe) fertilizer at various reproductive stages on yield, yield component and chemical composition of soybean (Glycine max L. Merr.) seed. African Journal of Biotechnology, 11(40), 9599-9605. https://doi.org/10.5897/AJB11.3568 
25. Sudarić, A. (2011): Soybean - Molecular Aspect of Breeding. Monograph book, Rijeka.

26. Sudarić, A., Vratarić, M., Pejić, I., Pospišil, A., \& Kolak, I. (2012): Soja. Oplemenjivanje poljoprivrednog bilja u Hrvatskoj. Kozumplik, V. i Pejić, I. (ur.), Zagreb, Sveučilište u Zagrebu, Agronomski fakultet: 72-77.

27. Sudarić, A., Vratarić, M., Volenik, M., Matoša, M., \& Duvnjak, V. (2009). Heterosis and heterobeltiosis for grain yield components in soybean. Poljoprivreda, 15(2), 26-31.

28. Tomić, F. (2012). Razvoj poljoprivrede primjenom navodnjavanja u Bjelovarsko-bilogorskoj županiji. Radovi Zavoda za znanstvenoistraživački $i$ umjetnički rad $u$ Bjelovaru, (6), 1-15.

29. Umburanas, R. C., Yokoyama, A. H., Balena, L., Lenhani, G. C., Teixeira, A. M., Krüger, R. L., Reichardt, K., \& Kawakami, J. (2018). Sowing dates and seeding rates affect soybean grain composition. International Journal of Plant Production, 12(3), 181-189.

https://doi.org/10.1016/j.eja.2016.03.002
30. Valinejad, M., Vaseghi, S., \& Afzali, M. (2013). Starter nitrogen fertilizer impact on soybean yield and quality. International Journal of Engineering and Advanced Technology (IJEAT), 3(1), 24-29. https://doi.org/10.2134/agronj2006.0089

31. Varnica, I., Petrović, S., Rebekić, A., Guberac, S., Jukić, K., \& Jukić, G. (2018). Karakterizacija i povezanost komponenti prinosa soje [Glycine max (L.) Merrill] tijekom sušne i vlažne godine. Journal of Central European Agriculture, 19(2), 466-481.

https://doi.org/10.5513/JCEA01/19.2.2148

32. Vratarić, M., Sudarić, A. (2008): Soja - Soybean Glycine $\max$ (L. Merr.) Book. Poljoprivredni institut Osijek, Vratarić (ed.), Osijek.

33. Zhang, T., Lin, X., \& Sassenrath, G. F. (2015). Current irrigation practices in the central United States reduce drought and extreme heat impacts for maize and soybean, but not for wheat. Science of the Total Environment, 508, 331-342.

https://doi.org/10.1016/j.scitotenv.2014.12.004

\section{EFEKT NAVODNJAVANJA I GNOJIDBE DUŠIKOM NA PRINOS SJEMENA SOJE S KORELACIJOM U ODNOSU NA KONCENTRACIJU BJELANČEVINA I ULJA}

\section{SAŽETAK}

U radu su prikazani rezultati trogodišnjih poljskih pokusa (2013. - 2015.), s ciljem utvrđivanja utjecaja navodnjavanja, gnojidbe dušikom i sorte te njihove interakcije na prinos i kemijska svojstva zrna soje. Ispitivane su četiri sorte soje (Lucija, Vita, Ika $i$ Tena) različitih grupa zriobe kao pod--podčimbenik (C). Analizom varijance utvrđeno je da se glavni čimbenik ( $A$ - navodnjavanje) statistički vrlo značajno $(P \leq 0,01)$ odrazio na prinos zrna u svima trima godinama. Podčimbenik (B - gnojidba dušikom) imao je utjecaja na prinos zrna zavisno o godini istraživanja, dok je pod-podčimbenik (C - sorta) značajno utjecao na sva ispitivana svojstva. Interakcije čimbenika i njihova značajnost razlikovale su se prema godini istraživanja. Ostvareni prinos zrna u 2013. godini (3883 $\left.\mathrm{kg} \mathrm{ha}^{-1}\right)$ ukazuje na veliko značenje međusobnoga djelovanja svih čimbenika. Tijekom istraživanja utvrđene su korelacije između prinosa sjemena $i$ koncentracije bjelančevina $i$ ulja.

Ključne riječi: soja, navodnjavanje, gnojidba dušikom, sorta, prinos sjemena, koncentracija bjelančevina sjemena, koncentracija ulja sjemena

(Received on June 26, 2020; accepted on October 27, 2020 - Primljeno 26. lipnja 2020.; prihvaćeno 27. listopada 2020.) 